THE EUROPEAN

DE GRUYTER OPEN

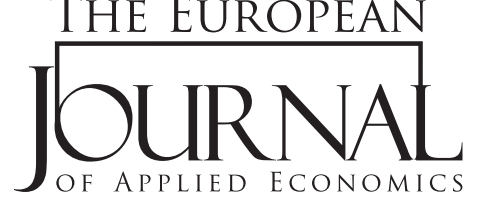

EJAE 2017, 14(1): 1-12

ISSN 2406-2588

UDK: 338.48(497.11)

$338.487: 339.13$

DOI: $10.5937 /$ ejae14-13088

Original paper/Originalni naučni rad

\title{
SERBIA'S COMPETITIVE POSITION IN THE REGIONAL TOURISM DESTINATION MARKET
}

\author{
Milivoj Teodorović ${ }^{1}$, Jovan Popesku ${ }^{2}$ \\ ${ }^{1}$ Singidunum University, \\ 32 Danijelova Street, Belgrade, Serbia \\ ${ }^{2}$ Singidunum University, \\ 32 Danijelova Street, Belgrade, Serbia
}

\begin{abstract}
:
The paper analyzes a competitive position of Serbia as a destination in the regional tourism market. The regional market includes Serbia's neighboring countries enhanced by Austria, Slovenia and Greece to provide a better view of the competitive landscape of the Southeast European region, herein termed the "Extended Balkans". The gap analysis was applied to the selected number of global secondary indices to highlight the differential effects that impact Serbia's position in different domains and categories, which in turn, has a profound effect on Serbia's ability to attract, delight and retain visitors. The emphasis of this theoretical paper is placed on the concept and methodology rather than on the selection of indices. The paper caters to both practitioners and academics by contributing to the literature on destination competitiveness through the lens of the positioning theory.
\end{abstract}

\section{Key words:}

gap analysis, destination positioning, destination competitiveness, importance-performance map.

\section{INTRODUCTION}

In today's tourism destination marketplace, countries are increasingly striving to attract more visitors, fulfill their expectations and prompt them to talk about their impressions and, ultimately, repeat their positive experience. Therefore, countries are looking for ways, tools, practices, and marketing strategies to track and guide their activities in order to achieve the desired performance levels. Tourism is the world's third largest industry, after fuels and chemicals, accounting for $10 \%$ of the world's GDP, $7 \%$ of the world's total exports, employing one in eleven people worldwide and growing at an annual rate of 4-5\% (UNWTO, 2016). Despite the fact that tourism is susceptible to the world's crisis scenarios, it is an industry that bounces back quickly.At the global scale, tourism is an opportunity and a source of wealth for the humanity in the years to come. However, the complex and multifaceted nature of the tourism industry, due to large number 
of stakeholders and diversity of challenges and experiences, makes the industry both promising and a risky venture for participants on either the demand or the supply side.

Many countries consider tourism to be almost the entire source of their economic output (Maldives, Seychelles, etc.). It is a significant income generator in developed countries, and a challenge for developing countries (Montenegro, Croatia, Slovenia, Hungary, etc.). Moreover, for most developing countries, it still remains an elusive goal, an unexplored venture and an opportunity on hold. Europe continues to lead the tourism market with 620 million arrivals in 2016, followed by Asia \& the Pacific with 303, the Americas with 201, Africa with 58 and the Middle East with 54 million arrivals. In 2016, Northern Europe, Central and Eastern Europe, and Southern Mediterranean showed an increase in arrivals by $6 \%, 4 \%$ and $1 \%$ respectively (UNWTO, 2017).

Serbia inevitably finds itself in the middle of the tourism market that is substantially growing, but the question remains as to whether it is maximizing its opportunities in comparison to the region and, consequently, global trends. The paper elaborates on how Serbia measures up against other countries in the region, and the region itself, and what strategic options it has at its disposal. The problem with many countries is the lack of index measurement system in place that will track a country's position against the competition (Dupeyras \& MacCallum, 2013). The Travel and Tourism Competitiveness Index (TTIC) places Serbia at 95th position out of 141 countries. The same report ranks Serbia 35th in Europe, only ahead of Albania and Moldova. The TTIC index, although an useful and good starting point, presents only a small part of the big picture, since it uses the same set and type of dimensions and indicators for each country. In this paper, we argue that each country should adopt its optimal and unique set of indices and indicators, as a measurement set, one that will address tangible and intangible specifics of a country, and use them for positioning of the country as a destination. The argument supports the notion that every country is comprised of a unique set of features and attributes that constitute its identity. In addition, those attributes constitute an authentic perception that creates an image offered to visitors. It is the reputation or image of a country that visitors take with them back home, as a perception of the experience they obtained while consuming the country's resources. Consequently, people talk about their experiences and consider them when planning their next trip.

Therefore, the problem appears to be in the selection and interpretation of measuring instruments that will more closely match the specifics and intrinsic attributes of the region. Consequently, in addition to the TTCI indicator, we propose several additional global empirical indicators to take part in measuring, evaluating and tracking of Serbia's performance as a tourism destination. The proposed set of indicators is by no means exhaustive, but rather a good starting point, which will be fine-tuned and improved over time. The emphasis is actually on the gap analysis for tracking and interpreting the difference between optimal points in order to better formulate point-of-parity and point-of-difference evaluations and strategies.

\section{LITERATURE REVIEW}

The effective positioning of a country as a destination is more critical today having in mind that tourism markets are becoming increasingly competitive. Popesku (2011) argues that the competition among tourism destinations reflects the competitive nature of all other human activities, thus suggesting that the competitive capability of a tourism destination points to the levels of the socio-economic development and the quality of life in a tourism destination. Similarly, a more comprehensive argument can be found in the sustainable nature of destination 
competitiveness manifested in the social, economic and human aspects (Popesku, 2011).

The reason for being competitive is not only the fact that tourism markets are becoming substitutable as they are mushrooming at the high rate, and offering new locations and experiences (Pike, 2005). Some estimates suggest that over $70 \%$ of the tourists visit up to 10 countries, mostly those within short or mediumhaul distances. Only 30\% are left as a potential segment willing to explore more countries and travel farther away (Morgan et al., 2002). However, there has been a lack of consensus when it comes to defining the concept behind the destination brand as an ultimate positioning construct by both practitioners and scholars (Park et al., 2006). From both supply and demand side, the destination brand is considered a (1) set of brand elements, (2) set of associations of expected experiences as a result of visitors' consumption of destinations' assets, (3) bridge between cognitive, affective and conative elements between the brand and visitors, and (4) means to reduce risk and the search cost (Blain et al., 2005).

Therefore, destination branding and positioning brings benefits to both sides of the spectrum, leading ultimately to higher arrivals and receipts and more importantly to visitors' loyalty (Aaker 1991, 1996). Besides increasing profits to local businesses stakeholders and tourism routers, destination marketing organizations (DMOs) can enhance loyalty and ultimately compete with other destinations on the basis of difference and parity (Kotler \& Keller, 2012). On the other hand, travelers use brand identity to lower search cost, match their perceived notions with expected experiences, reduce risk and enhance the overall value of the service via co-creation.

The area that has recently gained a lot of interest among academics and scholars is tracking destination brand positioning performance over time. This is an activity that tracks gaps between the actual destination brand performance and the position intended by the brand identity (Morgan et al., 2002). Furthermore, the importance of the gap analysis is to facilitate (1) increase in investments by DMOs, (2) increase in competition, (3) adjustment of positioning of the brand image and (4) increase in accountability by DMOs to stakeholders. In general, many marketing research initiatives have pointed to the lack of instruments to measure marketing performance effectiveness of the destination objectives (Pike, 2009). In 2004, the journal Place Branding and Public Diplomacy was launched by Anholt (2004) to address the vacuum between academic, research, scholar and public communities related to place branding as opposed to tourism destination branding. The place branding is a wider concept that besides tourism includes exports, trade, human development, public policy, cultural, historical and sport dimensions, hence all the elements of a nation.

Pike (2009), in his review of 74 publications, has pointed to nine different research gaps related to the brand destination. Among those mentioned, he pointed that the gaps in literature exist for measuring destination brand performance over time suggesting that Aaker's $(1991,1996)$ and Keller's $(1993,2002)$ concept of customer-based brand equity (CBBE), which Konecnik \& Gartner (2007) used to measure brand performance, is gaining attention. On the other hand, Aaker (1996) points that the objective should be for visitors to remember the destination for the right reasons. Furthermore, he discusses if the destination comes to mind when thinking about travelling, since travelers tend to narrow down the number of choices to four. Keller (2013) suggests that destinations to be considered must project strong, favorable and unique associations.

Many scholars and academics agree that the most empirical and theoretical research effort was geared towards brand equity of products (Konecnik \& Gartner, 2007), while many agree that the service side of the destination 
markets was left in the vacuum by the research community (Boo et al. 2009). Many scholars give advantage to the destination brand image, whereas less work is done on the destination's brand value. Recent literature review efforts exhibit pressure from different communities to increase genuineness and meaningful quality by borrowing terminology, such as "Destination Brand Equity" from already established customer and corporate branding theory (Kladou et al., 2015).

Since tourists value destinations based on how they are perceived by visitors, a customer-based brand equity concept emerged as a frontrunner, as the underlining concept for the model of measuring and tracking the destination value. Therefore, the image, rather than any other brand equity dimension, attracted the greatest attention of the research community (Gartner \& Ruzzier, 2011). Similarly, Lee et al. (2015) argue that for creating strategies, programs and plans, destination image enunciate convenient measuring dimension. According to Schroter \& Schwekendiek (2015), national image is a resource that can be explored from the point of democracy, social stability, security, cultural attractiveness, power, economic development, protection of law and trade. Also, Ritchie and Crouch (2010) argue that cost-to-value ratio augmented by attractiveness and competitive position are responsible for creating positive, favorable and unique feelings in the consumers' minds about the consumed products and services or those expected to be consumed. They further argue that the cost is a vital indicator for destinations to create an expectations effect.

Similarly, Mihailovich (2006) suggests that destination brands must exhibit strong efforts in gaining lasting positive relationship and trust with visitors. Globalization is a phenomenon that puts the country or nation's reputation into the front row of the global tourism destination arena (Buhmann \& Ingenhoff, 2013; Go \& Govers, 2011). Globalization is far from being fair, but has a significant impact on how countries com- municate, trade, influence opinions and attitudes about them (Vardar, 2013; Ashworth \& Kavaratzis, 2010; Buhmann \& Ingenhoff, 2013). Therefore, a very common argument among scholars is how to use country's image as an instrument to facilitate a country's development. Many academics agree that nations should adopt country brand positioning strategy (Brand Finance, 2015; Anholt, 2004). Furthermore, a county's positioning strategy must match government interests, political strategies and the capability of organizations responsible for a country's positioning (Marruti \& Tench, 2015). Therefore, governments are increasingly interested in making their country brands more sophisticated in value and attractiveness. The governments are looking into fund development, promotions, management, performance levels to gain higher ground advantage over the competition when it comes to negotiations, political debates and discussions (Anholt, 2004).

Moilanen and Rainisto (2009) argue that countries can benefit from the marketing positioning theory when it comes to promoting a country's brand in the destination markets. However, despite the large number of country destination models, a number of scholars and practitioners agree that there is still no comprehensive model for positioning a country as a destination brand (Marruti \& Tench, 2015). The number of models and related literature is constantly increasing, but one-model-fits-all is still a long way ahead. Buhmann and Ingenhoff (2013) argue that in order to develop a model that will comprehensively capture all aspects of the country's positioning, it is necessary to include constructs such as aesthetic, scenic and attractiveness aspect. In addition, there are many researchers who believe that country's brand positioning is a multifaceted and multilevel concept.

There are numerous models for global positioning of a country based on its perceived image. Anholt's GfK Roper National Brand Index, Future Brands' Country Brand Index, CBSI's 
Country Brand Strength Index, Brand Finance's National Brand Strength Index are some of the most interesting instruments supported by other set of indices such as GDP, Human Development Index, Travel and Tourism Competitiveness Index (TTCI) by the World Economic Forum (WEF) and variety of UN and World Bank statistics. According to Fabiutti \& Tench (2015), the dimension analysis of indices revealed that tourism is identified as a major dimension followed by immigration, governance, investments, exports, culture and heritage, economy, trade and people. At the same time, science, technology, sports, quality of life, value system were less associated with the people's perception of a country brand. Many scholars agree that perceptions and attitudes, though left out from the evaluation of the models, are an essential part of every country's brand model (Fetscherin, 2010; Dupeyras \& MacCallum, 2013). According to Dupeyras \& MacCallum (2013), a mix of future, current and past oriented indicators should be considered to ensure more accurate measurement of the tourism destination competitiveness. This is also in line with the OECD Tourism Committee position. Difficulties in selecting indicators, combined with the view on decision making process related to the country's brand positioning in the future, are cited as the main reasons for selecting a diverse set of indicators, leading the OECD to suggest the use of Travel \& Tourism Competitiveness Index and Nation Brand Index (Dupeyras \& MacCallum, 2013).

Only a few countries have put in place country-to-country competitiveness measures to monitor their position in the global tourism markets (Marruti \& Tench, 2015). Even though most countries use Travel \& Tourism Competitiveness Index and Country Brand Index (Future Brand, 2015), the ideal number of indicators may vary from country to country (Marruti \& Tench, 2015). Practitioners and schars have produced a significant body of literature on the countries' brand models from both business and research perspective. The business aspect is concerned with valuations of the performance, receipts, arrivals, rankings, improvements, image levels and public impression of the country (Buhmann \& Ingenhoff, 2013; Marruti \& Tench, 2015).According to Kotler and Keller (2012), a holistic approach must be used when determining which variables and corresponding indicators to use to correspond to internal, integrated, relational and performance dimensions of a country's positioning model.

\section{EXTENDED BALKANS REGION}

The region selected for the analysis is based on the neighborhood criteria, so called "Extended Balkans", and comprises the countries that are immediate neighbors of Serbia and former Yugoslav republics, which are geographically located in the Balkan region. Austria is added to the list because of its proximity to the region, as well as for its leading role as a tourism destination, as shown in Fig. 1.

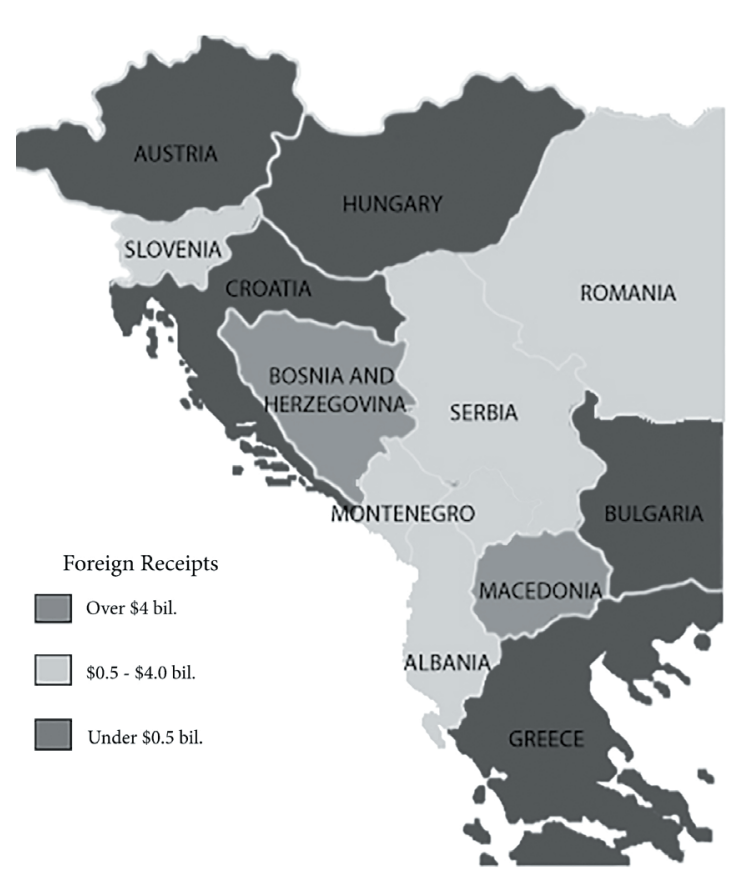

Figure 1. Extended Balkan Region by

Receipts (Source: www.pinterest.com). 
The region is a $\$ 1.1$ trillion economy with a population of 82 million, which in 2015 attracted 89 million visitors and cashed in $\$ 67$ billions in receipts. Serbia's share was 1.1 million in foreign visitors and $\$ 1.3$ billion in receipts or $1.16 \%$ and $1.69 \%$ of the regional

\begin{tabular}{|c|c|c|c|c|c|}
\hline No. & Country & $\begin{array}{c}\text { Population } \\
\text { (Mil.) } \\
\text { NFA 2014 }\end{array}$ & $\begin{array}{l}\text { GDP (\$Bil.) } \\
\text { IMF } 2016\end{array}$ & $\begin{array}{l}\text { Arrivals (000) } \\
\text { NFA } 2014\end{array}$ & $\begin{array}{c}\text { Receipts (\$Mil.) } \\
\text { NFA } 2014\end{array}$ \\
\hline 1 & Albania & 3.15 & $\$ 12$ & 3.000 & 1.705 \\
\hline 2 & Austria & 8.43 & $\$ 385$ & 25.291 & 20.559 \\
\hline 3 & $\mathrm{~B} \& \mathrm{H}^{*}$ & 3.84 & $\$ 16$ & 536 & 707 \\
\hline 4 & Bulgaria & 7.33 & $\$ 49$ & 7.311 & 4.134 \\
\hline 5 & Croatia & 4.32 & $\$ 50$ & 11.623 & 9.866 \\
\hline 6 & Greece & 11.12 & $\$ 195$ & 22.033 & 17.793 \\
\hline 7 & Hungary & 10.00 & $\$ 118$ & 12.139 & 5.844 \\
\hline 8 & Macedonia & 2.1 & $\$ 10$ & 425 & 295 \\
\hline 9 & Montenegro & 0.62 & $\$ 4$ & 1.350 & 906 \\
\hline 10 & Romania & 21.81 & $\$ 182$ & 1.912 & 1.813 \\
\hline 11 & Serbia $^{* *}$ & 7.20 & $\$ 37$ & 1.029 & 1.139 \\
\hline 12 & Slovenia & 2.06 & $\$ 44$ & 2.411 & 2.719 \\
\hline otal & & 81.98 & $\$ 1.102$ & 89.060 & 67.520 \\
\hline
\end{tabular}

${ }^{*}$ B\&H Bosnia and Herzegovina; ${ }^{*}$ Serbia without Kosovo and Metohia; Table 2. Extended Balkan Region.

figures, respectively. In 2014, the leader in the region was Austria with 25 million arrivals and \$20 billion in receipts, followed by Greece and Croatia, which collected $\$ 18$ billion and $\$ 10$ billion in receipts, respectively.

Globally, the extended Balkan region accounts for $7.5 \%$ and $6.5 \%$ of the global arrivals and receipts, respectively. On the other hand, the region attracts $15 \%$ and $17 \%$ of the total European arrivals and receipts, respectively. Consequently, the region on average outperforms both European arrivals and receipts per capita growth performance. In recent years, South Eastern region has been gaining popularity among visitors, who in pursuit of new experiences and discoveries are looking into the region to satisfy their curiosity and fulfill their aspirations with a new, mystical, unknown world that is basically at their footsteps, just waiting to be discovered. However, the region is not uniform in its ability to attract visitors. As a matter of fact, there is a considerable difference between the top performing countries in the region, Austria and Greece, and the bottom ones, Macedonia and Bosnia and Herzegovina. 


\section{METHODOLOGY}

The database frame was developed based on the thirty-three global empirical indicators representing perceptions of different initiatives covering economical, social, environmental, human development, innovation, marketing and destination and tourism competitive aspects of the selected region. The indices of each country in the region are averaged and compared to those of Serbia. Analyzing how Serbia measures up with the average of each index demonstrates where Serbia stands in a particular category, as shown in Fig. 2. The differences or gap levels, for each index between Serbia and the region, are plotted in the importance-performance map (IPM) analysis. The IPM, as an analytical tool, developed by Martilla and James (1977), has a wide use in analyzing positioning in the destination marketing literature (Chen \& Wells, 1999; Pike 2000, 2002; Dwyer, 2015). To further analyze information presented in Fig 2. the IPM maps are utilized to highlight the hot spots and relevant points. The quadrants in the IMP map are filled out based on the performance level in the gap diagram shown in Fig. 2, thus reflecting suggestions and opinions by different researchers and scholars from the literature review.

The gap analysis, as shown in Fig. 2, shows that there is a significant negative outlook of Serbia's position based on the indices selected. It shows that Serbia falls significantly behind, on average

\section{Serbia vs. Region's Average}

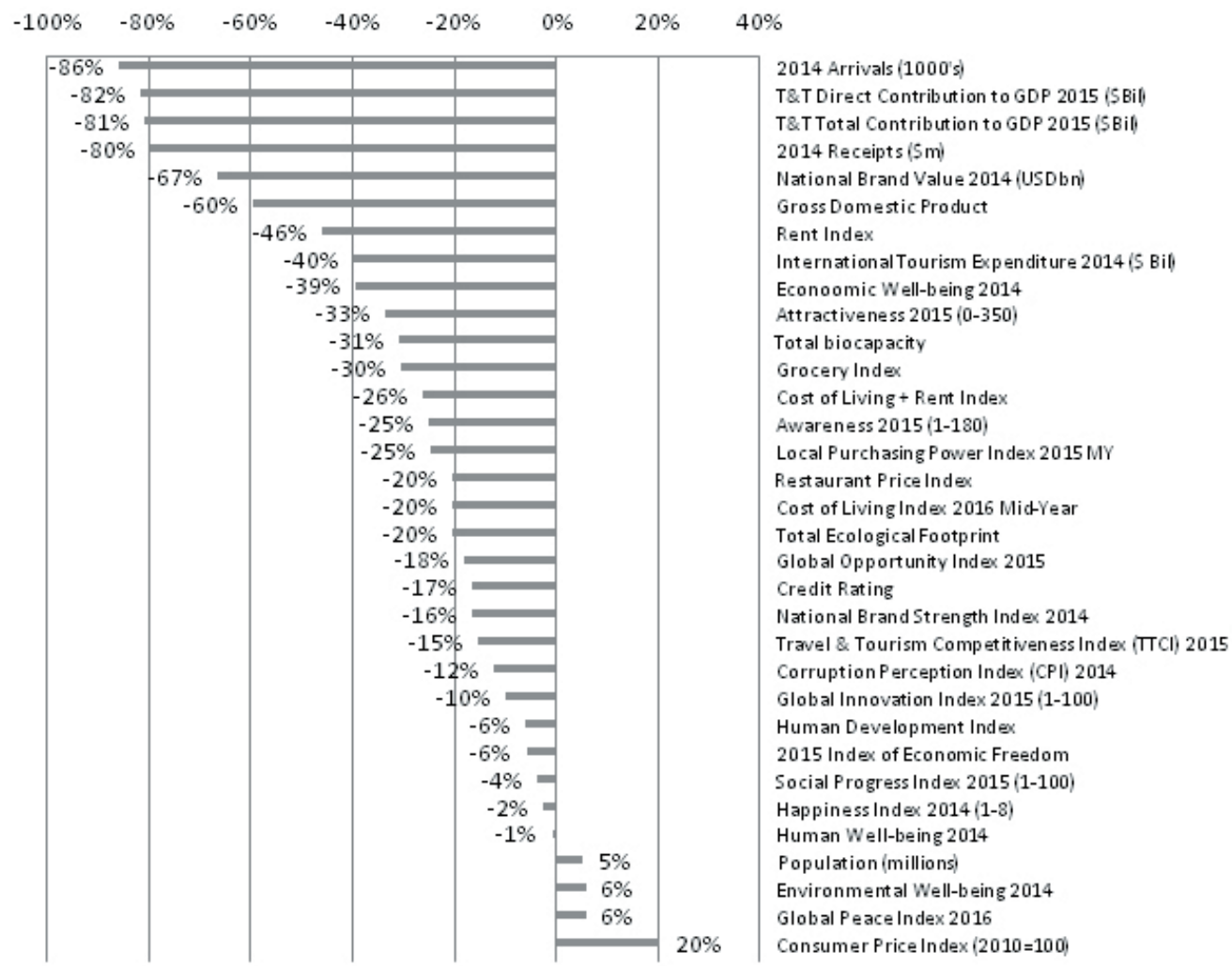

Figure 2. Serbia vs. Region: Gap Diagram Based on Thirty-Three Global Indices. 
$80 \%$, in the areas of arrivals, receipts, national brand value, GDP and both in direct and total contributions of its tourism revenue to GDP. It is followed by negative levels of attractiveness, awareness, tourism expenditure and local purchasing power and low standard of living. On the other hand, Serbia shows competitiveness in price levels of groceries, res- taurants, living and rent. However, all the benefits that Serbia offers as a destination do not seem to be enough to provide the attractive cost-benefit ratio for visitors. Furthermore, Serbia is about $15 \%$ below the region's mean for ecological footprint, investment attractiveness, and country risk, strength of the national image, destination competitivness, corruption, innovation

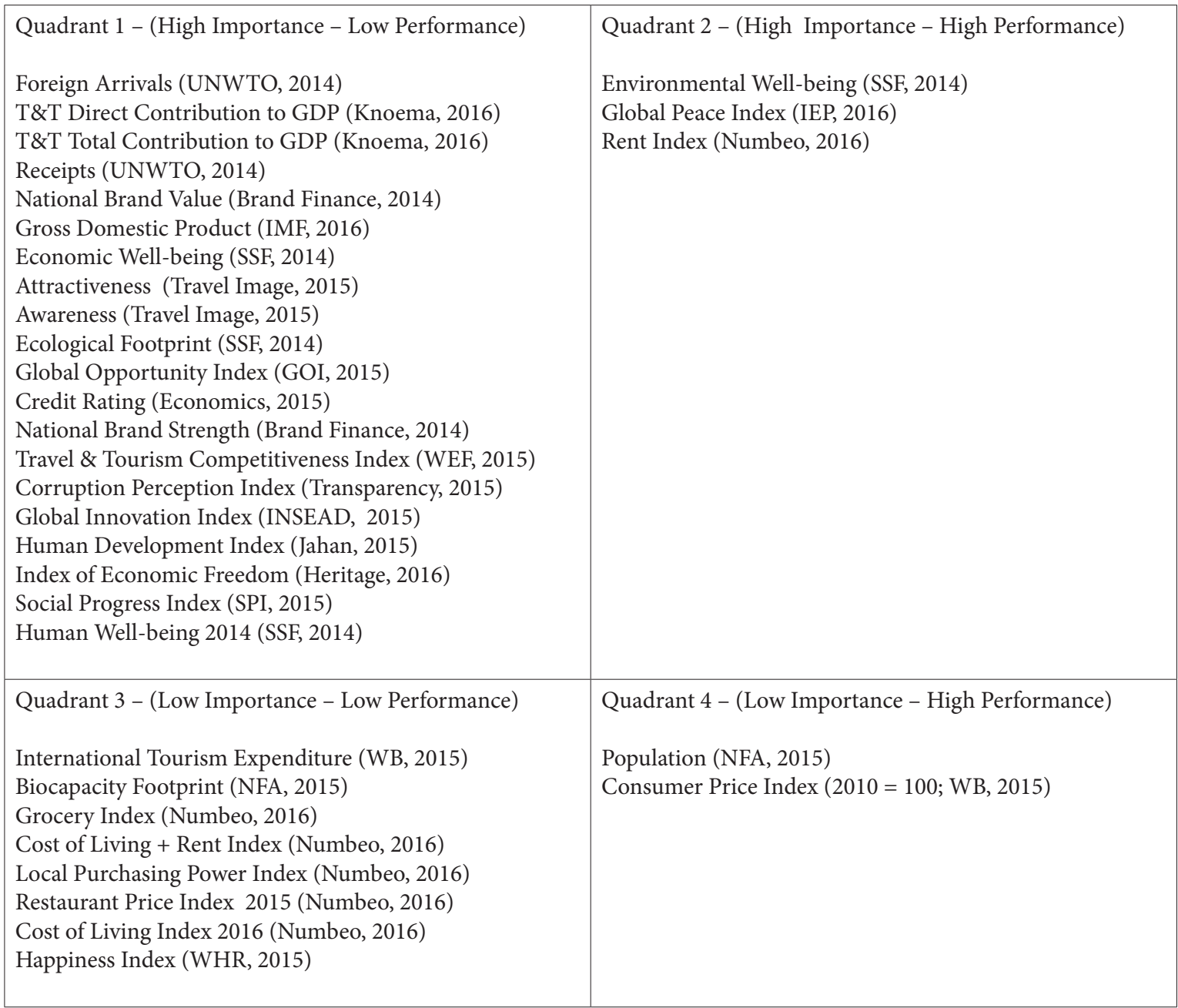

Table 1. Extended Balkan Region.

and human development. Furthermore, Serbia's human well-being, economic freedom, social progress and happiness index are somewhat less negative, but still below the average for the region. On the positive side, Serbia scores higher on the population size, state of the environment, global safety and inflation. Population and country size are one of the prerequisites for higher national brand value. The significance of the overall Serbia's position is captured in the IPM table, as shown in Table 1. 


\section{THE OUTLOOK}

The first quadrant of the IMP map identifies the performance in the most significant areas that constitute the back bone of the positioning elements of Serbia as a destination. The map shows that Serbia is falling behind in the majority of indicators that are deemed important in the analysis. In particular, the most severe gaps, $80 \%$ below the region's average, are in the level of foreign receipts and arrivals, contribution to GDP, and the national brand value. This indicates that Serbia has not sufficiently integrated tourism into its national and global strategic development programs. On the other hand, the gap of $40 \%$ in economic wellbeing, attractiveness, awareness, sustainability and investments indicates that Serbia is lacking efficient and effective integrated marketing communication programs combined with a favorable business climate that will attract foreign investments, both green-field and brown-field. This leads to the lack of attention to the environment, unattractive investment climate, undeveloped infrastructure and the overall low standard of living. Serbia as a destination is slow to effectively advertise its attractiveness and, consequently, scores very low on awareness, i.e. $25 \%$ below the region's average. Its most known locations are Belgrade, Novi Sad, and the winter/summer resorts Kopaonik and Zlatibor, but the rest of the country's cultural, archeological, historical, scenic and hereditary treasure is relatively unknown to the global community. Furthermore, Serbia has not clearly defined its points-of-parity and points-of-difference positioning strategy and is not explicit on its frame of reference in the region (Kotler \& Keller, 2012). In terms of corruption index, Serbia is $12 \%$ below the region's average and its national brand strength is on average below $16 \%$. The negative gaps continue in single digits for innovation, freedom of doing business and human development.

The second quadrant shows areas that are important and in which Serbia performs well and measures up better than the region. Serbia's impact on the environment is at the region's average or slightly better. That can be explained by undeveloped economy rather than environmental friendly practices. On the other hand, Serbia is a relatively safe place to visit, with the low risk of unexpected catastrophic events. Furthermore, low cost of accommodation is an attractive offer, but again, it is mostly the result of the weak demand and undeveloped supply.

The third quadrant outlines the areas of relatively low importance, not significant for Serbia's position even if Serbia does not perform well in those areas. It is worth mentioning that the price levels are about $25 \%$ below the region's average. The argument can be made that low prices attract visitors, but only if there are perceived benefits or reasons reasons (Aaker, 1996). In other words, low price levels alone are not enough to attract visitors if there is no underlying value structure that creates the perception of getting value for money. On the other hand, Serbia's bio-capacity and satisfaction levels, even though below the region's average, are not considered to play a significant and relevant role in Serbia's positioning as a destination.

The fourth quadrant identifies areas in which Serbia excels, but without significant impact on Serbia's position. Inflation levels, although not severe, have little impact on the values of foreign currency and in some cases, can have positive effects on the attractiveness of Serbia as a destination. On the other hand, the size of the population is not considered significant in this study, at least not in the Balkan region. 


\section{CONCLUSION}

The center of gravity of the region, as presented in Fig. 1, shows the above average performance at the outskirts of the region and the gap in the middle of the region with two countries, Macedonia and Bosnia and Herzegovina, falling significantly behind. On the other hand, Slovenia, with 2014 foreign receipts just under $\$ 3$ billion, is expected to do much better, mostly because of its scenic, infrastructure, hereditary and cultural resources, as well as because of its proximity to Central and Western Europe.

Furthermore, the analysis shows that Serbia falls below the region's average according to twenty-nine out of thirty-three global indicators. The only pockets of the above average performance are in prices of accommodation, impact on the environment and global safety. The most significant finding of the paper is that Serbia does not have in place the tracking mechanism for monitoring its competitiveness, reputation, awareness and attractiveness of the position in the global tourism destination marketplace. In particular, it is evident that Serbia lacks a comprehensive strategy for improving its position in the region and globally. In addition to the high level strategy initiative, the herein conducted research reveals the areas where Serbia needs to improve its current position and standings. Those include awareness, attractiveness, contribution to GDP, value and strength of the country's brand, reputation, sustainable practices, corruption, legal and business climate, innovation, ease of doing business, human development and competitiveness. The holistic approach suggests that the overall improvements of Serbia's position will come as a synergy of advances in numerous different areas, which will contribute to the final and ultimate positioning of Serbia in the regional and global destination market.

\section{REFERENCES}

Aaker, D. (1996). Building Strong Brands. New York: The Free Press.

Aaker, D. (1991). Managing Brand Equity. New York: The Free Press.

Anholt, S. (2004). Editor's foreword to the first issue. Place Branding and Public Policy, 1(1) , 4-11.

Ashworth, G., \& Kavaratzis, M. (2010). Place branding: where do we stand? In A. Gregory, \& M. Kavaratzis, Towards Effective Place Brand Management. Branding European Cities and Regions (pp. 1-14). Northampton: Edward Elgar Publishing.

Blain, C., Levy, S., \& Ritchie, J. (2005). Destination branding: Insights and practices from destination management organizations. Journal ofTravel Research, 43(May), 328-338.

Boo, S. Y., Busser, J. A., \& Baloglu, S. (2009). A model of customer-based brand. Tourism Management, 219-231.

Brand Finance. (2015). Nations Brands 2015. London: Brand Finance.

Buhmann, A., \& Ingenhoff, D. (2013). Advancing the Country Image Construct from a Public Relations Perspective: The Constitution of the County Image and its Effect on Travel Behavior. EUPRERA 2013 Congress, (pp. 1-17). Barcelona Spain.

Chen, Q., \& Wells, W. D. (1999). Attitude Toward the Site. Journal of Advertising Research, 39(5), 27-38.

Dupeyras, A., \& MacCallum, N. (2013). Indicators for Measuring Competitiveness in Tourism: A Guidance Document. Paris: OECD Publishing.

Dwyer, L. (2015). Destination Competitiveness: Challenges for Transition Economies. Ljubljana: Faculty of Economics, University of Ljubljana.

Economics, T. (2015). Credit Rating. Retrieved December 2,2015, from Trading Economics: http://www.tradingeconomics.com/country-list/ ratingFabiutti, M., \& Tench, R. (2015, January). Are we talking the same language? Challenging complexity in country brand models. Athens Journal of Business and Economics, 49-61.

Fetscherin, M. (2010). The determinants and measurement of a country brand: the country brand strength index. International Marketing Review, 27(4), 466-479. 
Future Brand. (2015). Country Brand Index 2014-15. Future Brand. Retrieved December 2,2015, from Future Brand: http: //www.futurebrand.com/ uploads/CBI-14_15-LR.pdf

Gartner, W. C., \& Ruzzier, M. K. (2011). Tourism Destination Brand Equity Dimensions: Renewal versus Repeat Market. Journal of Travel Research, 50(5), 471-481.

Go, F. M., \& Govers, R. (2011). International place branding yearbook 2011: managing reputational risk. Individual chapter's contributors. London: Palgrave Macmillan.

GOI. (2015). Global Opportunity Index. Santa Monica: Milken Institute.

Heritage. (2016). 2016 Index of Economic Freedom. Retrieved July 20, 2016, from Heritage: http://www. heritage.org/index/

IEP. (2016). Global Peace Index 2016. New York: Institute for Economics and Peace.

IMF. (2016). Report for Selected Countries and Subjects. Retrieved July 20, 2016, from International Monetary Fund: https://www.imf.org

INSEAD. (2015). The Global Innovation Index 2015. Geneva: Cornell University, INSEAD and World Intellectual Properties.

Jahan, S. (2015).Human Development Report 2015. New York: UNDP.

Keller, K. (1993). Conceptualizing, measuring, and managing customer-based brand equity. Journal of Marketing, 57(1) , 1-22.

Keller, K. L. (2013). Strategic Brand Management. In K. L. Keller, Strategic Brand Management Building, Measuring and Managing Brand Equity. Essex: Pearson.

Keller, K. L., \& Lehmann, D. R. (2002). Measuring Brand Equity. Hanover, NH: Dartmouth College, Working Paper.

Kladou, S., Giannopoulos, A. A., \& Mavragani, E. (2015). Destination Brand Equity Research from 2001 to 2011. Tourism Analysis, 20, 189-200.

Knoema. (2016). Travel \& Tourism Total Contribution to GDP. Retrieved July 15, 2016, from Knoema: https://knoema.com/atlas/ topics/Tourism/Travel-and-Tourism-TotalContribution-to-GDP/Total-Contributionto-GDP-percent-share
Konecnik, M., \& Gartner, W. C. (2007). Customerbased brand equity for a destination. Annals of Tourism Research, 400-421.

Kotler, P., \& Keller, K. L. (2012). Marketing Management. Upper Saddle River, NJ: Prentice Hall.

Lee, H., Ju-Pak, K.-H., \& i Hong, M. (2015). Comparative Perspectives on Brand Value of Place Slogans: Analysis of Different Cities, States, and Countries. American International Journal of Social Science,40(2), 59-70.

Marruti, F., \& Tench, R. (2015). Are we talking the Same Language? Challenging Complexity in Country Brand Models. Athens Journal of Business and Economics, 49-61.

Martilla, J., \& James, J. (1977). Importance-Performance Analysis. Journal of Marketing (pre-1986), 41(000001), 77-79.

Mihailovich, P. (2006). Kinship Branding: A Concept of Holism and Evaluation for the Nation Brand. Place Branding, 2(3), 229-247.

Moilanen, T., \& Rainisto, S. (2009). How to brand nations, cities and destinations: a planning book for place branding. London: Palgrave Macmillan.

Morgan, N., Pritchard, A., \& Piggott, R. (2002). New Zealand, $100 \%$ Pure. The creation of a powerful niche destination brand. Journal of Brand Management, 9(4-5), 335-354.

NFA. (2015). National Footprint Accounts. Oakland, CA: Global Footprint Network.

Numbeo. (2016, April 2). Cost of living. Retrieved December 2, 2015, from Numbeo: http:// www.numbeo.com/cost-of-living/

Park, S., \& Petrick, J. (2006). Destinations' perspectives of branding. Annals of Tourism Research, 33(1), 262-265.

Pike, S. (2009). Destination brand positions of a competitive set of near-home destinations. Tourism Management, 30(6), 857-866.

Pike, S. (2002). Destination Image Analysis. A review of 142 papers from 1973-2000. Tourism Management, 23(5), 541-549.

Pike, S. (2000). The use of importance-performance analysis to identify determinant short break destination attributes in New Zealand. Pacific Tourism Review, 6(2), 23-33. 
Pike, S. (2005 ). Tourism destination branding complexity. Journal of Product \& Brand Management, 14(4), 258-259.

Popesku, J. (2011). Menadžment turističke destinacije. Beograd: Univerzitet Singidunum. In Serbian.

Ritchie, J. B., \& Crouch, G. I. (2010). A Model of Destination Competitiveness/Sustainability: Brazilian Perspectives. Revista de Administracao Publica, 44(5), 1049-1066 .doi:10.1590/S003476122010000500003

Schröter, T. Y., \& Schwekendiek, D. (2015). Understanding South Korea's Poor Nation Brand Image: A Content Analysis of Two Leading German Print News Media, 1948-2013. International Journal of Asia Pacific Studies, 11(1), 115-135.

SPI. (2015). Social Progress Index 2015. Washington: Social Progress Imperative.

SSF. (2014). Sustainable Society Index. Retrieved December 2, 2015, from Sustainable Society Foundation: http://www.ssfindex.com/about-ssf/

Transparency. (2015). Corruption Perception Index 2015. Retrieved December 2, 2015, from Transparency International: http://www.transparency. org/cpi2015
TravelImage. (2015). Travel Image 2015. Stockholm: Related.

UNWTO. (2014). Annual Report 2014. Madrid:World Tourism Organization.

UNWTO. (2016). UNWTO Tourism Highlights, 2016 Edition. Madrid: World Tourism Organization.

UNWTO. (2017). UNWTO World Tourism Barometer. Madrid: World Tourism Organization

Vardar, N. (2013). Recent trends in global advertising practice, beyond the fundamentals. Retrieved October 2, 2013, from http://hstalks.com. ezproxy.leedsmet .ac.uk/

WB. (2016). International Tourism Expenditures. Retrieved July 20, 2016, from World Bank: http://data.worldbank.org/indicator/ ST.INT.XPND.CD

WEF, W. E. (2015). Travel and Tourism Competitiveness Report. Geneva: World Economic Forum.

WHR. (2015). World Happiness Report 2015. New York: Sustainable Development Solutions Network.

\section{KONKURENTSKA POZICIJA SRBIJE NA REGIONALNOM TURISTIČKOM TRŽIŠTU}

\section{Rezime:}

Rad analizira konkurentsku poziciju Srbije kao turističke destinacije na regionalnom turističkom tržištu. Regionalno turističko tržište obuhvata zemlje susede Srbije uz dodatak Austrije, Slovenije i Grčke, kako bi se dobila celovitija slika regiona jugoistočne Evrope koji u radu nazivamo „Prošireni Balkan”. Izabrani skup globalnih indikatora je analiziran metodom jaza kako bi se pojasnio uticaj različitih efekata koji utiču na poziciju Srbije u pojedinim domenima i kategorijama, što zauzvrat ima značajan uticaj na mogućnosti Srbije da privuče, zadovolji i zadrži turiste. Težište ovog rada je više na konceptu i metodologiji, a manje na izboru indeksa. Rad je namenjen kako praktičarima, tako i akademskom sektoru, dajući doprinos literaturi koja se odnosi na konkurentnost turističkih destinacija posmatranih kroz prizmu teorije pozicioniranja.

\section{Ključne reči:}

analiza jaza,

pozicioniranje destinacija, konkurentnost destinacija, mapa važnost-učinak. 